\title{
EDITORIAL
}

\section{In This Issue: Glimpses of a Transformed Model of Care}

\author{
Kurt C. Stange, $M D, P b D$, Editor \\ Conflicts of interest: none reported \\ Ann Fam Med 2006;4:98-100. DOI:10.1370/afm.545.
}

\section{TRANSITIONING TO A NEW MODEL OF HEALTH CARE}

$\mathrm{T}$

The Future of Family Medicine Report ${ }^{1}$ calls for

a New Model of care ${ }^{2}$ that is grounded in time-

less values of personalized, patient-centered care coupled with the application of new technologies and systems. Economic modeling of the transition to this New Model shows that the changeover is likely to engender short-term costs before the hypothesized transformed practice is reached. ${ }^{3}$

Multiple articles in this issue provide insights into elements of the New Model and the challenges of making the transition to it within the constraints of the current health care "system."

The study by Fortin and colleagues ${ }^{4}$ and the editorial by Starfield ${ }^{5}$ highlight the need for focusing evidence on the realties of the types of patients who need care. Fortin et al show that most patients treated for hypertension in primary care have multiple chronic conditions, whereas the clinical trials and practice guidelines based on these trials often exclude patients with comorbidities. Starfield outlines action steps needed to design health care and its evidence base to represent the way patients seek care in real life apart from clinical trials. A transformed practice requires relevant evidence, disease management that integrates care for multiple illnesses, and mechanisms to generate and use relevant new knowledge if it is to succeed.

An in-depth qualitative analysis of an exemplary practice points the way to developing practice systems that integrate preventive and chronic illness care. ${ }^{6}$ This practice scores highly on multiple quality measures that span the domains of chronic disease care and prevention. The attributes identified in this practice include components of a transformed practice, such as patientcenteredness, strong support for the physician-patient relationship, a team approach to care, and transpar- ent, data-based, accountable systems. The attributes also encompass key features of a change management process that includes strong visionary leadership, organized change management, an improvement orientation, and a sense of ownership and responsibility, as well as pride and joy in their work.

The Chronic Care Model ${ }^{7}$ has been developed to guide systematic efforts to improve health care for people with chronic illness. In this issue Schmittdiel and colleagues $^{8}$ examine the relationship of the Chronic Care Model with 8 measures of the primary care orientation of 957 physician organizations. The association of 6 of these measures with the implementation of the Chronic Care Model shows the potential benefit of providing an improved primary care home.

Electronic health records are a cornerstone of the New Model practice. A comprehensive ethnographic study by Ventres and colleagues ${ }^{9}$ shows how implementation of an electronic health record influences multiple cognitive and social aspects of the clinician-patient encounter. This study raises important and empirically answerable questions about how to better use the electronic health record to enhance the relationship as well as instrumental aspects of care.

To meet patient needs abundantly, the efforts of practices need to be leveraged with new support systems. The study by Woolf and colleagues evaluates such a Web-based system that offers tailored health advice and local and national resources. The succinct main article ${ }^{10}$ highlights lessons learned from the implementation of this novel technology, and a detailed supplemental appendix provides information on development of the Web site and data on its effect on patient behavior change. ${ }^{11}$

Decision support services are an important component of transformed practices. A clinical trial by Westfall and colleagues in the High Plains Research Network ${ }^{12}$ finds that the addition of a decision aid vali- 
dated in other settings does not improve the already high rate of diagnostic accuracy among patients with chest pain seeking care at 10 rural hospitals. Implementation of new technologies in real-world practice settings cannot be assumed to improve care, particularly when that care already is of high quality.

The study by Won and Dembe shows that in a nationally-representative sample of patients seen for work-related conditions, most care provided by family physicians involves the patient's regular physician. ${ }^{13}$ The finding that visits to family physicians for occupational injuries or illnesses involve care for other conditions shows the potential for current primary care practice to integrate care for multiple conditions. New Model practices are hypothesized to improve this important ability to integrate care by enhancing access, providing a defined basket of services, and supporting team-based and ongoing care. Such integration may result in improved quality and lower cost. ${ }^{14-18}$

Two essays in this issue inform different aspects of the New Model of care. The essay by Loxterkamp ${ }^{19}$ provides a personal face to an important problem affecting primary care patients_opioid dependence. The story shows how an office-based treatment program benefits from time and relationships that require great personal effort to develop and maintain in the current system. The family physician author reflects on our need to examine our beliefs as well as our systems if we are to optimize care.

An essay by 5 Robert Wood Johnson Foundation Generalist Scholars and a member of their National Advisory Committee presents a blueprint for active collaboration among the generalist disciplines. ${ }^{20}$ Such collaboration is likely to lead to a greater focus on the critical role of primary care in changing the health care system to meet patient and population needs, rather than a focus on meeting the needs of physicians. Ironically, such an outward focus, as opposed to selfdirected attention, is more likely to meet the needs of primary care clinicians. ${ }^{21}$

The coherence of similar analyses by pediatrics ${ }^{22}$ and internal medicine ${ }^{23}$ disciplines highlights opportunities for the primary care fields to collaborate with all who care about equitable, high-quality, sustainable health care in system redesign. The commonality of purpose also cries out for leadership that works to overcome disciplinary boundaries to find shared purpose around improving the ability of primary care to fulfill its mission in fostering quality health care for all. ${ }^{16}$

Together, these articles highlight both the potential and the challenges of making the transition to a new model of care. They point to the need for new kinds of scientific evidence about the integration of care and about the process of conducting large-scale transfor- mation that brings new benefits while not destroying much of what currently is good. They show the need for systems to support the both the transition and the maintenance of high-quality primary care. ${ }^{24}$

\section{OTHER INSIGHTS FOR CLINICAL PRACTICE AND POLICY}

A prospective cohort study by McGovern and colleagues ${ }^{25}$ examines symptoms among women 5 weeks after delivery. The findings of continued symptoms, particularly among women whose delivery was by cesarean section or who breastfeed suggest a need for support, efforts to reduce the cesarean delivery rate, and more extended maternity leave than is common in the United States. ${ }^{26}$

Methicillin-resistant Stapbylococcus aureus (MRSA) is an important cause of difficult-to-treat and life-threatening infections. ${ }^{27}$ In this study using a nationally representative sample, more than 2.2 million people carry MRSA, whereas the prevalence of colonization of $S$ aureus involves nearly one third of the population. ${ }^{28}$ These findings highlight the need for greater attention to infection control procedures and avoidance of unnecessary antibiotics.

We welcome all Annals readers to participate in the online discussion of articles at http://www.AnnFamMed. org.

To read or post commentaries in response to this article, see it online at http://www.annfammed.org/cgi/content/full/4/2/98.

Acknowledgments: I appreciate Larry Green's helpful comments on this editorial and Robin Gotler's vital input into every In this Issue.

\section{References}

1. Future of Family Medicine Project Leadership Committee. The future of family medicine: a collaborative project of the family medicine community. Ann Fam Med. 2004;2(Suppl 1):S3-S32.

2. Task Force 1 Writing Group. Task Force 1. Report of the Task Force on Patient Expectations, Core Values, Reintegration, and the New Model of Family Medicine. Ann Fam Med. 2004;2 (Suppl 1):S33-S50.

3. Stephen J. Spann for the members of Task Force 6 and The Executive Editorial Team. Report on Financing the New Model of Family Medicine. Ann Fam Med. 2004;2 (Suppl 3):S1-S21.

4. Fortin M, Dionne J, Pinho G, Gignac J, Almirall J, LaPointe L. Randomized controlled trials: do they have external validity for patients with multiple comorbidities? Ann Fam Med. 2006:4:104-108.

5. Starfield B. Threads and yarns: weaving the tapestry of comorbidity. Ann Fam Med. 2006;4:101-103.

6. Solberg LI, Hroscikoski MC, Sperl-Hillen JM, Harper PG, Crabtree BF. Transforming medical care: case study of an exemplar small medical group. Ann Fam Med. 2006;4:109-116

7. Wagner EH, Austin BT, Von Korff M. Organizing care for patients with chronic illness. Milbank Quarterly. 1996;74:511-544.

8. Schmittdiel JA, Shortell S, Rundall T, Bodenheimer T, Selby J. Effect of primary health care orientation on chronic care management. Ann Fam Med. 2006;4:117-123. 
9. Ventres W, Kooienga S, Vuckovic N, Marlin R, Nygren P, Stewart V. Physicians, patients, and the electronic health record: an ethnographic analysis. Ann Fam Med. 2006;4:124-131.

10. Woolf $\mathrm{SH}$, Krist $\mathrm{AH}$, Johnson $\mathrm{R}$, et al. A practice-sponsored Web site to help patients pursue healthy behaviors: an ACORN study. Ann Fam Med. 2006;4:132-136.

11. Woolf $\mathrm{SH}$, Krist AH, Johnson R, et al. A practice-sponsored Web site to help patients pursue healthy behaviors: an ACORN study. Ann Fam Med. 2006;4:132-136. Supplemental Appendix. Available at: http:// www.annfammed.org/cgi/data/4/2/132/DC1/.

12. Westfall JM, Van Vorst RF, McGloin J, Selker HP. Triage and diagnosis of chest pain in rural hospitals: implementation of the ACI-TIPI in the High Plains Research Network. Ann Fam Med. 2006;4:137-142.

13. Won JU, Dembe AE. Services provided by family physicians for patients with occupational injuries and illnesses. Ann Fam Med. 2006;4:143-152.

14. Starfield B. New paradigms for quality in primary care. Br J Gen Pract. 2001;51:303-309.

15. Starfield B. Primary Care: Balancing Health Needs, Services, and Technology. New York: Oxford University Press; 1998.

16. Donaldson M, Yordy K, Lohr K, Vanselow N. Primary Care. America's Health in a New Era. Washington, DC: National Academy Press; 1996.

17. Institute of Medicine. Crossing the Quality Chasm: A New Health System For the 21st Century. Washington, DC: National Academy Press; 2001.

18. Showstack J, Lurie N, Larson EB, Rothman AA, Hassmiller SB. Primary care: the next renaissance. In: Showstack J, Rothman AA, Hassmiller SB, eds. The Future of Primary Care. San Francisco: Jossey-Bass; 2004

19. Loxterkamp DA. Helping them: our role in recovery from opioid dependence. Ann Fam Med. 2006;4:167-170.
20. Kutner JS, Westfall JM, Morrison EH, Beach M, Jacobs EA, Rosenblatt RA. Facilitating collaboration among academic generalist disciplines: a call to action. Ann Fam Med. 2006;4:171-175.

21. Easwaran E. Your Life is Your Message. Tomales, California: Nilgiri Press; 1993.

22. American Academy of Pediatrics Medical Home Initiatives for Children with Special Needs Project Advisory Committee. The medical home. Pediatrics. 2003;110:184-186.

23. Larson EB, Finn SD, Kirk LM, et al. The future of general internal medicine. Report and recommendations from the Society of General Internal Medicine (SGIM) Task Force on the Domain of General Internal Medicine. J Gen Intern Med. 2004;19:69-77.

24. TransforMED. Consultation and support for primary care practices that want to implement the New Model of care as outlined in the Future of Family Medicine report. American Academy of Family Physicians [Internet Website]. Available at: http://www.aafp.org/x40604. xml. Accessed 28 December 2005.

25. McGovern PM, Dowd B, Gjerdingen D, et al. Postpartum health of employed mothers 5 weeks after childbirth. Ann Fam Med. 2006:4:158-166.

26. US Census Bureau. Maternity Leave and Employment Patterns: 1961 1995. United States Census Bureau Web site. Available at: http:// www.census.gov/prod/2001pubs/p70-79.pdf. Accessed: 18 February 2006.

27. Kluytmans-Vandenbergh MF, Kluytmans JA. Community-acquired methicillin-resistant Staphylococcus aureus: current perspectives. Clin Microbiol Infect. 2006;12(Suppl 1):9-15

28. Mainous AG, Hueston WJ. Everett CJ, Diaz VA. Nasal carriage of Staphylococcus aureus and methicillin-resistant Staphylococcus aureus in the United States, 2001-2002. Ann Fam Med. 2006;4:0-0. 